How understanding past landscapes can inform present day site investigations: A case study from Dogger Bank, southern central North Sea

Cotterill, $\mathrm{C}^{1}$., Phillips, $\mathrm{E}^{1}$., James, $\mathrm{L}^{2}$., Forsberg, C. $\mathrm{F}^{3}$. and Tjelta, T. $\mathrm{I}^{4}$.

1 - British Geological Survey, Lyell Centre, Research Avenue South, Edinburgh, EH14 4AP, cjcott@bgs.ac.uk

2 - RPS Energy

3 - Norwegian Geotechnical Institute

4 - Statoil 


\begin{abstract}
The integration of geophysical and geotechnical datasets acquired during a site survey for the Dogger Bank windfarm has enabled a new litho-and seismo-stratigraphy to be established. Although previously believed to be a relatively simple "layer-cake", the data reveals that the sedimentary sequence within the foundation zone includes a complex series of buried landscapes with implications for both foundation siting and design. The most significant is a glacially derived landscape dominated by a large thrust-block moraine complex buried beneath a thin Holocene sequence. This glacial landscape profoundly affects the structure and physical properties of soils within the foundation zone due to locally intense glacitectonic deformation, and the occurrence of sub-aerially desiccated horizons recording fluctuating palaeoclimatic conditions. Understanding these landscapes, coupled with the geophysical and geotechnical data, enables a predictive "geo-model" to be established which can be used to target areas of uncertainty, reducing the requirement for boreholes (over CPTs) at every potential foundation location.
\end{abstract}




\section{Introduction and background}

The Dogger Bank is an isolated, approximately E-W-trending topographic high situated within the central and southern North Sea Basin spanning both UK and Dutch territorial waters (Figure 1a). The evolution of the Dogger Bank is linked to a complex interplay between climatic variation, sea level changes (both rise and fall) and ice sheet movement. Throughout the Quaternary there have been three major glacial periods, with ice advancing across the North Sea Basin. Evidence suggests that during the most recent period, termed the Weichselian, ice inundated the Dogger Bank on more than one occasion (Balson and Cameron 1985; Sejrup et al. 1987; Cameron, Stoker and Long, 1987; Cameron et al. 1992; Sejrup et al. 1995; Sejrup et al. 2000; Sejrup et al. 2003; Graham, Lonergan and Stoker 2007; Kristensen et al., 2007; Bradwell et al. 2008; Stoker et al. 2011; Graham et al. 2011; Stewart, Lonergan and Hampson 2013; Ottesen, Dowdeswell and Bugge 2014). However, the actual limits of these major ice masses within the southern North Sea are poorly understood and constrained (Catt 1991; Sejrup et al. 2009). , Until recently this lack of understanding was further compounded by the fact that very little was known about the Quaternary and Holocene soils underlying the Dogger Bank area and forming the Dogger Bank itself.

In 2008 the Crown Estate announced the opening of nine development zones within UK waters for offshore windfarm leasing, the largest of which was the Dogger Bank Zone (Figure 1a). As a result, high resolution geophysical and ground truthing datasets were acquired by the Forewind Consortium (Statoil, Statkraft, RWE and SSE) between 2010 and 2014. Prior to these surveys the stratigraphy and structure of the Dogger Bank was believed to be a relatively simple "layer-cake" with much of the upper $60 \mathrm{~m}$ of the 
Quaternary sedimentary sequence being assigned to the Dogger Bank Formation (DBF) (Balson and Cameron 1985; Cameron et al. 1992). The formation was described as a c. 40-50 m thick sequence of variably consolidated glacigenic soils comprising generally stiff to very stiff clays containing multiple sand-rich layers. However, interpretation of the recently acquired high-resolution site investigation data has proven that this is far from the case.

Utilising this new data Cotterill et al. (in press) have subdivided the Dogger Bank Formation into three informal units, the Basal, Older and Younger Dogger Bank, based on the geotechnical responses of the soils combined with lateral extent of significant seismic reflectors. In detail the Basal unit comprises a series of discrete, laterally discontinuous bank-like deposits which occur immediately above the marine sands of the underlying Eem/Egmond Ground formations. The Older and, to a lesser extent, Younger units within the DBF both show evidence of locally intense, southerly directed folding and thrusting as a result of glacitectonic deformation. These deformed sediments locally dominate the upper $60 \mathrm{~m}$ of the Quaternary sequence on the Dogger Bank. Consequently, understanding the glacitectonic deformation recorded within the DBF is a critical issue for the development of a windfarm on the Dogger Bank.

\section{Methodology}

During the earlier stages of the analysis of turbine locations for the proposed offshore windfarm, a number of areas were identified as being complex with regards to deformation within the Older and Younger DBF, with the deformation signatures recording the advance and/or retreat of ice across the area. In order to understand the impacts of this glacier induced deformation on conditions within the foundation zone a 
pilot study was instigated focused upon the south-western part of the Dogger Bank Zone (Figure 1a). An horizon map constructed for the top surface of the deformed Older DBF (Figure 1b) not only revealed the extent of glacitectonism within the study area, but also the presence of a buried glacial landscape (see Results). This horizon map was used to select three key areas for further detailed study (Figure 1b)

- Area 1 - an approximately NE-SW-trending zone located in the northwestern part of the study area where the proposed, ridge-like glacial landforms are less apparent;

- Area 2 - an elongate NE-SW-trending zone located within the central part of the study area where the glacial landforms are better developed and therefore likely to provide a clearer indication of the internal structure of these features; and

- Area 3 - a smaller NW-SE-trending zone located in the SE corner of the study area.

Eleven seismic profiles (line spacing $300 \mathrm{~m}$ to $1500 \mathrm{~m}$ apart) from these three areas were selected for analysis in order to gain an understanding of the nature and lateral variation in the relative intensity of deformation recorded by the Older DBF. The profiles all occur approximately orthogonal to the trend of the proposed glacial landforms (see Figure 1b) and are therefore aligned parallel to the potential direction of ice-push responsible for any glacitectonic deformation. Consequently the seismic profiles provide a series of structural cross-sections through the landforms and therefore likely to provide the most complete record of glacitectonism.

For ease of analysis each seismic profile was cut into a series of overlapping sections and exported from IHS Kingdom ${ }^{\circledR}$ as high-resolution digital image files (jpegs). These 
images were imported into a commercial computer graphics package (CorelDraw version X6 (64 bit)). A graphics package was used for the detailed structural analysis as it not only allows individual reflectors of the seismic profiles to be digitised, but also enables the attribution of different line styles to particular geological structures (e.g. bedding, fold axes, thrusts, faults), and colour coding of polygons representing individual seismo/tectonostratigraphical units, and, where applicable, their constituent sedimentary subunits. These stratigraphical and sedimentary elements were identified on the basis of differences in their acoustic properties on the seismic profiles. Examples of the results of this analysis are shown as a series of structural cross sections through the DBF on Figures 2 and 3.

It must be stressed that the colour scheme used to distinguish between the sedimentary subunits present within the relatively undeformed part of the DBF sequence is not intended to infer any direct correlation of these subunits to seismostratigraphic units, but rather is used to highlight the geometry of these individual sediment packages. It is acknowledged that this method of interpretation pushes the seismic resolution to its limit. However, all interpretations have been checked for geological and structural integrity, ensuring that all mapped features have a solid, process based, geological foundation.

An approximate depth conversion was calculated to aid correlation of the identified structural/sedimentological features against potential turbine foundation depths, using the following velocities:

- Water Column@ 1550 m/s 
- Holocene @1600 m/s

- Upper Dogger Bank Formation @ 1680 m/s

- Lower Dogger Bank Formation @ 1750m/s

In order to fully integrate the soil physical properties data with other "geo" interpretations, a bespoke predictive model was developed by Norwegian Geotechnical Institute during the early stages of analysis of the site survey data. This approach allowed the integration of geotechnical and borehole data with geophysical interpretations and geological models of subsurface conditions. A number of borehole logs were retained to ground-truth the model. The more detailed process based interpretations of buried landscapes will serve to further refine the model predictions, enabling greater confidence in predicting ground conditions at each proposed turbine location.

\section{Results}

The driver for this detailed study was the horizon map constructed for the upper surface of the Older DBF, provided by Leo James of RPS Energy (Figure 1b). Strong reflectors marking the tops of both the Basal and Older DBF units on the seismic profiles are interpreted as desiccation (weathering)/subaerial exposure surfaces. The prominent, laterally extensive surface marking the top of the "Older” DBF has been mapped across the study area and, as previously stated, can be interpreted in terms of a buried glacial landscape (Figure 1c). The brown and yellow colours on the horizon map represent areas where the Older DBF upper surface occurs close to sea bed (minimum depth c. 2.5 m). In contrast, the darker green and blue colours indicate where this surface is located at a much deeper level (maximum depth c. $66 \mathrm{~m}$ below sea bed). The resultant pattern of “topographically higher” areas can be interpreted as defining a series of elongate, 
arcuate moraines separated by "low-lying" areas which are thought to represent as a series of ice-marginal to proglacial sedimentary basins and/or meltwater channels (Figure 1c); the later are filled by essentially undeformed Younger DBF soils. The horizon map therefore reveals the presence of a large (10-15 km across, 20-30 km long) moraine complex within the DBF (Figure 1c). This moraine complex appears to extend (laterally) beyond both the present study area and Dogger Bank Zone. Importantly, analysis of the seismic profiles has shown the moraines correspond to the thickest (up to 40-50 m thick) development of the deformed Older DBF.

Moraines typically occur parallel to the margin of an ice sheet and can therefore be used to chart the changing position of a former ice sheet margin. The crests of these ridgelike landforms are formed at $90^{\circ}$ to the ice movement direction; i.e. orthogonal to direction of ice-push (compression) responsible for the glacitectonic deformation. The relationship between these landforms, glacitectonic deformation (folding and thrusting) and the direction of ice-push are shown in Figure 4.

\section{Tectonostratigraphy}

As stated above Cotterill et al. (in press) have subdivided the DBF into three informal units. Although this tripartite subdivision was recognised on the seismic profiles from the areas 1 and 3 (Figures 2, 3a and b), this informal stratigraphy could not be easily applied to the seismic profiles from area 2 (Figure 3c). In this area the seismic profiles extend beyond the apparent southwestern limit of the moraine complex (see Figure 1b and c). To the south of the moraine complex the Younger DBF soils can be further divided into two (Figure 3c): (i) a structurally lower, acoustically transparent unit which is locally deformed and rests directly upon the strong reflectors marking the top of the 
deformed Older DBF; and (ii) a slightly “darker”, upper undeformed unit which contains bands of relatively bright reflectors interpreted as well-bedded soils. Unit (ii) is apparently separated from underlying unit (i) by a marked erosion surface (Figure 3c). On all the seismic profiles from Area 2 the relative intensity of deformation within unit (i) increases north-eastwards (i.e. towards the moraine complex) where these sediments appear to pass laterally into the more intensely deformed deposits equated with the Older DBF (Figure 3c). The acoustic appearance of the deformed parts of unit (i) and Older DBF are similar, making it difficult to identify the boundary between the two units suggesting that the deformed Older DBF is partially derived from the Younger part of the DBF. In an effort to solve this problem an informal tectonostratigraphy is proposed which divides the DBF into four units.

\section{Tectonostratigraphic Unit 1}

Tectonostratigraphic Unit 1 occurs in all three areas and largely corresponds to the Basal DBF of Cotterill et al., (in prep). It is the structurally lowest unit within the DBF with its upper surface being marked by a band of strong reflectors and is distinguished from the overlying sequence by its overall "darker” appearance on the seismic profiles. Unit 1 is laterally discontinuous ranging from absent up to c. $25-30 \mathrm{~m}$ thick and forms a series of ridge-like features on the seismic profiles (Figures 2 and 3). Reflectors within this unit are variably inclined (tilted), folded and thrusted due to glacitectonism. The degree of shortening (compression) accommodated by this unit is in marked contrast to the largely horizontally bedded, undisturbed sediments of the underlying pre-Dogger Bank sequence indicating that the base of the DBF, in addition to being a primary sedimentary/lithostratigraphical contact, is also a prominent, laterally extensive décollement surface (Figures 2 and 3). 


\section{Tectonostratigraphic Unit 2}

Tectonostratigraphic Unit 2 is typically an acoustically transparent unit which has currently only been recognised within Area 2 where it rests upon Unit 1 (Figure 3c). In general Unit 2 thickens towards the southwest, away from the southern limit of the moraine complex, and ranges in thickness from as little as $5 \mathrm{~m}$ up to a maximum of $\mathrm{c}$. 20-25 m. Weakly developed reflectors within Unit 2 are interpreted as bedding surfaces. Bedding within this unit is variably deformed (folded and thrusted) with the intensity of this deformation increasing towards the northeast.

\section{Tectonostratigraphic Unit 3}

Tectonostratigraphic Unit 3 occurs in all three areas and largely corresponds to the Older DBF of Cotterill et al., (in press) (Figures 2 and 3). The unit ranges from $0 \mathrm{~m}$ (absent) up to an apparent maximum thickness of c. 30-40 m thick where it dominates the DBF sequence. However Unit 3 is truncated at the base of the overlying Holocene sequence and/or sea bed (Figures 2 and 3), so its original thickness may have been far greater. The acoustic appearance of the unit is highly variable ranging from transparent, lacking reflectors and is apparently internally massive, through sections where it possesses weakly to strongly developed reflectors that are variably inclined (tilted), folded and thrusted due to locally intense glacitectonism. The reflectors are interpreted as representing not only bedding, but also major thrusts which propagate upwards through this highly deformed unit (Figure 3). Over much of the study area Unit 3 rests directly upon Unit 1 (Figures 2 and 3), however the precise nature of this boundary is uncertain. Due to the highly deformed nature of both units 1 and 3 it is likely that is boundary is tectonic (i.e. a décollement surface or thrust) or a tectonised sedimentary 
contact. Furthermore, parts of Unit 3 containing bands of strong reflectors are similar in appearance to the structurally underlying Unit 1, suggesting that Unit 3 may contain thrust-bound slices of the underlying Basal DBF.

\section{Tectonostratigraphic Unit 4}

Tectonostratigraphic Unit 4 occurs in all three areas (Figures 2 and 3) and largely corresponds to the Younger DBF (Cotterill et al., in press). The base of the unit is marked by an irregular erosive contact which locally cuts downwards into units 3, 2 and 1, as well as the underlying pre-Dogger Bank sequence (Figures 2 and 3a). The acoustic character of Unit 4 is laterally variable ranging from areas with no or very weakly developed reflectors through to sections with moderately to strongly developed subhorizontal to inclined reflectors interpreted as bedding surfaces. Changes in the acoustic appearance of Unit 4, coupled with changes in the inclination of bedding, have been used to identify a number of sedimentary subunits within this unit (Figures 2 and 3). The thickness of Unit 4 is highly variable ranging from absent ( $0 \mathrm{~m}$ thick) over the larger moraine ridges, up to c. 40-50 m within the intervening lower lying channels and basinal areas (Figures 2 and 3). Unit 4 is thickest in areas 1 and 2 where it is internally complex comprising a number of cross-cutting lenticular to laterally extensive tabular units. A thick Unit 4 sequence also occurs in the northwestern part of Area 3 where it rests upon a band of strong reflectors marking the top of the Unit 3 in this area (see Figure $3 b)$. 


\section{Structural and sedimentary architecture}

Although in detail the geometry of the four tectonostratigraphic units varies across the study area, a number of observations can be made regarding distribution of these units and their deformation:

- Deformation within units 1, 3 and, to a lesser extent, 2 is dominated by southerly directed thrusting and folding (Figures 2 and 3) consistent with glacitectonism having been driven by ice advancing from the north. In contrast, the sediments of Unit 4 are in general undeformed suggesting that their deposition largely post-dated deformation;

- The deformed sediments of Unit 1 form a series of ridge-like features $(0.5-3 \mathrm{~km}$ across and up to $40 \mathrm{~m}$ high; Figures 2 and 3) composed of locally intensely thrusted and folded sediments. These features which can be traced laterally across areas 1, 2 and 3 indicating that they may form linear bodies which appear to form the cores to the individual moraine ridges identified on the horizon map;

- Unit 2 only occurs within the southwestern part of Area 2 where it initially thickens south-westwards away from the southern limit of the moraine complex, subsequently thinning rapidly towards the margin of the study area where it is cut out by the overlying Unit 4 (Figure 3c). Consequently, Unit 2 is thought to form a 5-6 $\mathrm{km}$ wide apron mantling the southern margin of the moraine complex. The relative intensity of the deformation affecting Unit 2 increases towards the northeast where these sediments appear to pass laterally into the highly deformed Unit 3 (Figure 3c); 
- Unit 3 represents the most intensely deformed part of the DBF forming the main component of the moraines, indicating that they are glacitectonic landforms (thrust-block moraines). In areas 1 and 3 the individual thrust-block moraines range from 0.5 to $5 \mathrm{~km}$ across (Figures 2 and 3), and between 20 to $50 \mathrm{~m}$ high (estimates based upon the maximum present day thickness of Unit 3). The tops of the larger moraines are either masked by the strong seabed pulse, or have been truncated (eroded) during the deposition of Unit 4 and/or later Holocene sequence. In the central part of Area 2, Unit 3 forms the core to a 10 to $12 \mathrm{~km}$ wide zone of thrusting and folding (Figure 3c);

- The intensity of folding and thrusting in both Units 1 and 3, and thereby the amount of shortening accommodated by these tectonostratigraphic units, clearly indicates that the base of DBF is marked by a major décollement surface. This décollement appears to extend across most of the study area and will have modified the original relationship between the DBF and the underlying pre-DBF sequence;

- The upper part of the DBF is dominated by essentially undeformed sediments (Unit 4; Figures 2 and 3). The base of the Unit 4 is an irregular erosion surface which locally cuts downwards through the underlying tectonostratigraphical units into the underlying pre-DBF sequence. Where Unit 4 is more thickly developed it comprises a number of lenticular to more laterally extensive tabular subunits separated by erosion surfaces. The cross-cutting relationships between 
these sedimentary packages indicate that Unit 4 probably represents a complex glacial outwash sequence forming a series of aprons/deltas.

\section{Structural Domains}

For ease of description the deformed parts of the DBF (tectonostratigraphic Units 1, 3 and, to a lesser extent, 2) have been divided into 7 structural domains (Figure 3). The sediments within each domain exhibit a similar style and relative intensity of deformation.

- Domain 1 is dominated by southerly directed thrusting and folding of both units 1 and 2, and characterised by the progressive increase in the relative intensity of deformation northwards towards the southern margin of the moraine complex (Figure 3);

- Domain 2 is characterised by zones of well-developed, southerly directed thrusting and folding which affects units 1, 2 and 3 (Figure 3);

- Domain 3 represents zones of large-scale ( $\geq 1 \mathrm{~km}$ wavelength), upright folding within Unit 3 (Figure 3). The presence of these large-scale, warp-like folds is recognised by the change in vergence of parasitic mesoscale folds (50-200 m wavelength) developed on their limbs. Domain 3 is typically developed within the cores of the larger thrust-block moraines in Areas 1 and 2, as well as within the wide zone of thrusting and folding which dominates the DBF of Area 3;

- Domain 4 is dominated by stacked, elongate thrust-bound slices (1-2 km long) of Unit 3 sediments (Figure 3);

- Domain 5 is characterised by steeply inclined reflectors (bedding) and is interpreted as denoting zones of relatively intense folding and thrusting (Figure 3); 
- Domain 6 is the most widely developed of the structural domains and includes parts of Unit 3 where the reflectors are either very poorly developed or absent, suggesting that these sediments are either massive and/or highly disrupted due to deformation (Figure 3);

- Domain 7 only occurs in Area 1 and corresponds to large (0.5-1 km wide), deeply incised channels filled by a thick sequence of Unit 4 sediments. These ice-marginal to proglacial meltwater channels cut through the lower part of DBF (Units 1 and 2) and into the underlying pre-Dogger Bank Formation sequence (Figures 2 and 3).

\section{Conclusions and Discussion}

It is clear from the above description of the results of this preliminary study of the DBF within the southwestern part of the Dogger Bank Zone that this sequence of glacigenic sediments is far from being a simple layer-cake as previously thought (Balson and Cameron, 1985; Cameron et al., 1992). The recognition of a buried glacial landscape within the DBF (Figures $1 \mathrm{~b}$ and c), coupled with the detailed analysis of seismic profiles in three key areas (Figures 2 and 3), have revealed that the Dogger Bank is, at least in part, composed of a complex moraine system comprising variably deformed (folded and thrusted) sediments. The complexity of the structural and sedimentary architecture of the DBF within the foundation zone of the proposed offshore windfarm has profound implications for the siting and design of the turbine foundations. However, the process based approach adopted here to understanding this buried landscape has the potential to address many of the issues required to develop a predictive "geo-model" which can be used to target areas of uncertainty, reducing the requirement for boreholes (over CPTs) at every potential foundation location. 
Horizon mapping has clearly identified a suite of glacially derived features including moraine ridges which range from $0.5-3 \mathrm{~km}$ in width and up to $40-50 \mathrm{~m}$ in height. These internally complex glacitectonic landforms (thrust-block moraines) are composed of highly folded and thrusted Basal and Older DBF sediments. The base of this deformed sequence is marked by a prominent, laterally extensive décollement surface which separates the glacigenic sediments of the DBF from the underlying marine sands. The geometry of the folds and the sense of offset on the thrusts indicate that this deformation was driven by ice-push from the north. Although complex in nature, careful analysis of the data has allowed this glacitectonised sequence to be divided into seven structural domains each of which share a similar style and relative intensity of deformation. Recognising the seismic character of these structural domains means that their lateral extent can now be mapped outwith the three areas chosen for this detailed study, providing a qualitative tool for understanding/predicting likely geotechnical soil response and ground conditions.

The low-lying areas located between the moraine ridges are interpreted as representing either meltwater channels and/or much wider sedimentary basins which are filled as the ice retreated by a complex glacial outwash Younger DBF sequence (Figures 2 and 3). While the moraines represent periods of still stand and active advance of the ice sheet resulting in locally intense deformation and "rucking-up" of the sediments at its margin, the intervening basinal areas represent prolonged periods of retreat. The sediments within these basins exhibit very little, if any, evidence of deformation and are filled by horizontally bedded to laminated Younger DBF sediments. The Older DBF is typically much thinner in these areas. The larger of the meltwater channels are incising through 
the moraines to penetrate into the underlying pre-DBF sequence (Figure 2). The icemarginal to proglacial sedimentary basins and meltwater channels (see Figure 4) provide natural deposition sinks for material and become infilled with a complex mix of glacifluvial sands and finer glacilacustrine sediments as well as aeolian deposits which rework the exposed sandur surface. The physical properties of these outwash sediments may differ significantly from those forming the moraine ridges. The sediments filling the deeply incised channels have the potential to act as subsurface pathways for fluid and shallow gas migration, thereby locally altering the hydrodynamic regime within the foundation zone.

Analysis by colleagues at the Norwegian Geotechnical Institute have shown that the sediment (soil) stress history from Dogger Bank includes both mechanical and desiccation pre-consolidation mechanisms (pers. comm.). These both fit well within the developing geological process history, with significant evidence of ice loading, aerial exposure in times of ice retreat prior to later marine flooding, and changes to the hydrological regime evident through incised sub-glacial channel systems with different phases of infill and changes to the sediments laid down within these meltwater drainage systems.

This present study has shown that by refining the understanding of geological processes acting on an area, it is possible to identify the causes behind many of the geotechnical responses, and gain an insight into the extent, whether that be regional or localised, of those properties through tracing seismostratigraphic, tectonostratigraphic or soil units using seismic data. This can then be incorporated into a pre-existing or bespoke "geomodel” that integrates seismic horizon information along with geotechnical log data and 
geological landscape mapping. This approach is currently being applied to the remained of the Dogger Bank Zone and has the potential to provide valuable insights into the not only the geological evolution of this previously poorly understood region of the North Sea, but also the impact of this evolving geological landscape evolution model on the physical properties of the near surface sediments left behind.

\section{Acknowledgments}

The authors would like to thank the Forewind Consortium for sharing the site survey datasets used in this study, and for giving permission to publish the results. Emrys Phillips and Carol Cotterill publish with the permission of the Executive Director of the British Geological Survey, Natural Environmental Research Council. 


\section{References}

Balson, P. S. and Cameron, T. D. G. 1985. Quaternary mapping offshore East Anglia. Modern Geology, 9, pp. 221 - 239

Bradwell,T., Stoker, M. S., Golledge, N. R., Wilson, C. K., Merritt, J. W., Long, D. 2008. The northern sector of the last British Ice Sheet: maximum extent and demise. Earth Science Reviews, 88, pp. 207 - 226.

Cameron, T.D.J., Stoker, M.S. and Long, D. 1987. The history of Quaternary sedimentation in the UK sector of the North Sea Basin. Journal of the Geological Society, London 144, 43-58.

Cameron, T. D. J., Crosby, A., Balson, P. S., Jeffery, D. H., Lott, G. K., Bulat, J. and Harrison, D. J. 1992. United Kingdom offshore regional report: the geology of the southern North Sea. (London:HMSO for the British Geological Survey). 152pp

Catt, J. A., 1991. Late Devensian glacial deposits and glcaiations in eastern England and the adjoining offshore region. In: Ehlers, J., Gibbard, P. L. And Rose, J. (eds). Glacial deposits in Great Britain and Ireland. A.A. Balkema: Rotterdam. pp. 61-68.

Cotterill, C., Long, D., James, L., Forsberg, C. F., Phillips, E., Ruiter, A., Tjelta, T. I. and Dove, D. 2017. The evolution of the Dogger Bank, North Sea: a complex history of terrestrial, glacial and marine environmental change. Quaternary Science Review. In Press 
Graham, A. G. C., Lonergan, L. and Stoker, M. S., 2007. Evidence for Late Pleistocene ice stream activity in the Witch Ground basin central North Sea, from 3D seismic reflection data. Quaternary Science Review. 26, pp. 627-643.

Graham, A.G.C., Stoker, M.S., Lonergan, L., Bradwell, T., Stewart, M.A., 2011. The Pleistocene glaciations of the North Sea Basin. In: Ehlers, J. and Gibbard, P.L., (Eds.), Quaternary Glaciations - Extent and Chronology (2nd Edition), pp. 261-278. Elsevier, Amsterdam.

Kristensen, T. B., Huuse, M., Piotrowski, J.A. and Clausen, O.R. 2007. A morphometric analysis of tunnel valleys in the eastern North Sea based on 3D seismic data. Journal of Quaternary Science, 22(8), 801-815.

Ottesen, D., Dowdeswell, J.A. and Bugge, T. 2014. Morphology, sedimentary infill and depositional environments of the Early Quaternary North Sea Basin ( $56^{\circ}$ to $62^{\circ} \mathrm{N}$ ), Marine and Petroleum Geology, doi: 10.1016/j.marpetgeo.2014.04.007.

Sejrup, H.P., Aarseth, I., Ellingsen, K.L., Reither, E., Jansen, E., Løvlie, R., Bent, A., Brigham-Grette, J., Larsen, E., Stoker, M., 1987. Quaternary stratigraphy of the Fladen area, central North Sea: a multidisciplinary study. Journal of Quaternary Science 2, pp. 35-58. 
Sejrup, H.P., Aarseth, I., Haflidason, H., Løvlie, R., Bratten, Å., Tjøstheim, G., Forsberg, C.F., Ellingsen, K.L., 1995. Quaternary of the Norwegian Channel: glaciation history and palaeoceanography. Norwegian Journal of Geology 75, pp. 65-87.

Sejrup, H.P., Larsen, E., Landvik, J., King, E. L., Haflidason, H., and Nesje, A., 2000. Quaternary glaciations in southern Fennoscandia: evidence from southwestern Norway and the northern North Sea region, Quaternary Science Reviews, 19 (7), pp. 667-685.

Sejrup, H.P., Larsen, E., Haflidason, H., Berstad, I.M., Hjelstuen, B.O., Jonsdottir, H., King, E.L., Landvik, J.Y., Longva., O., Nygård, A., Ottesen, D., Raunholm, S., Rise, L., Stalsberg, K., 2003. Configuration, history and impact of the Norwegian Channel Ice Stream. Boreas 32, pp. 18-36.

Sejrup, H. P., Nygard, A., Hall, A. M. and Haflidason, H., 2009. Middle and late Weichselian (Devensian) glaciation history of south-western Norway, North Sea and eastern UK. Quaternary Science Review. 28, pp. 370-380.

Stewart, M. A., Lonergan, L and Hampson, G. 2013. 3D seismic analysis of buried tunnel valleys in the central North Sea: morphology, cross-cutting generations and glacial history. Quaternary Science Reviews, 72, pp.1 - 17. http://dx.doi.org/10.1016/j.quascirev.2013.03.016 
Stoker, M S, Balson, P S, Long, D, and Tappin, D R. 2011. An overview of the lithostratigraphical framework for the Quaternary deposits on the United Kingdom continental shelf. British Geological Survey Research Report, RR/11/03. 48pp. 


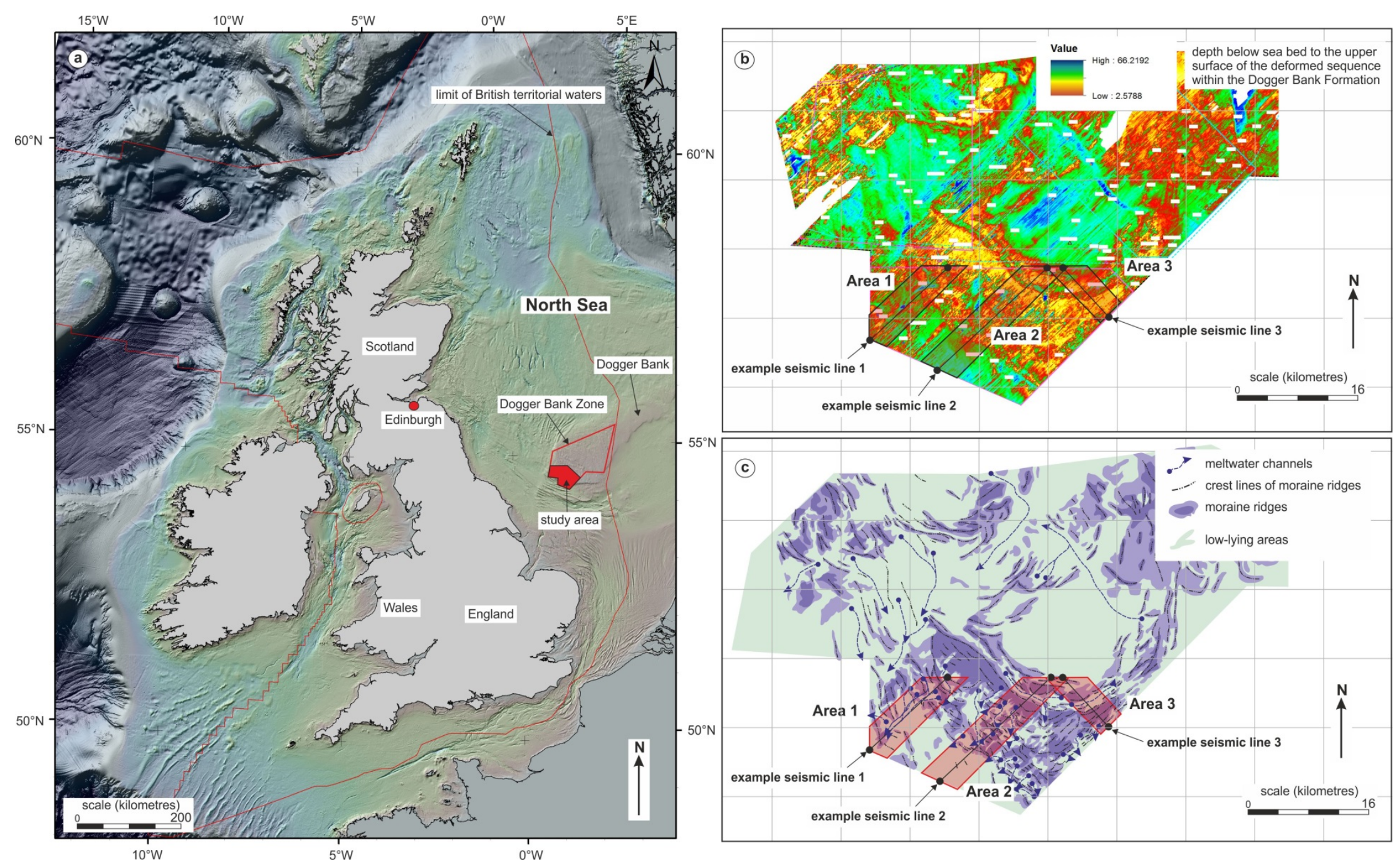

Figure 1 
(a) Example of structural interpretation of seismic profile from Area 1

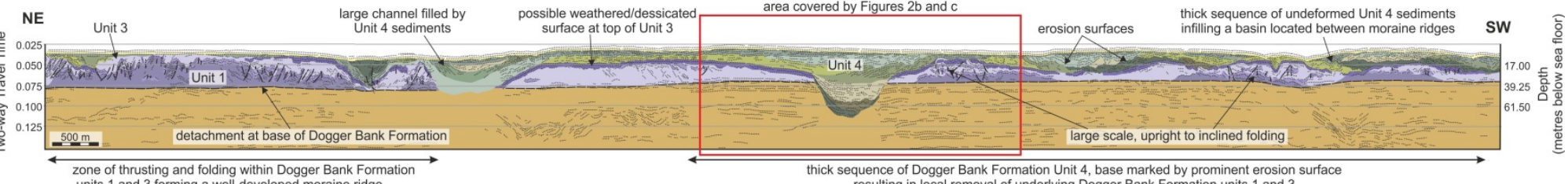

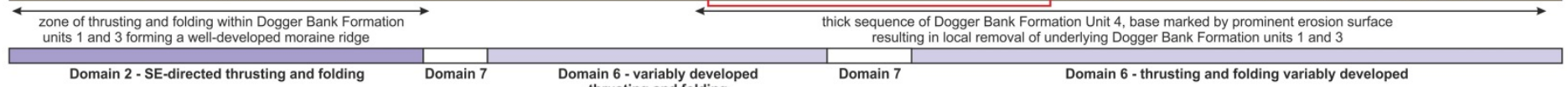

(b) $\mathrm{NE}$

Domain 2 - SE-directed thrusting and folding $\mid$\begin{tabular}{cc|c|c|} 
Domain 7 & $\begin{array}{c}\text { Domain 6 - variably developed } \\
\text { thrusting and folding }\end{array}$ & Domain 7 & Domain 6 - thrusting and folding variably developed
\end{tabular}

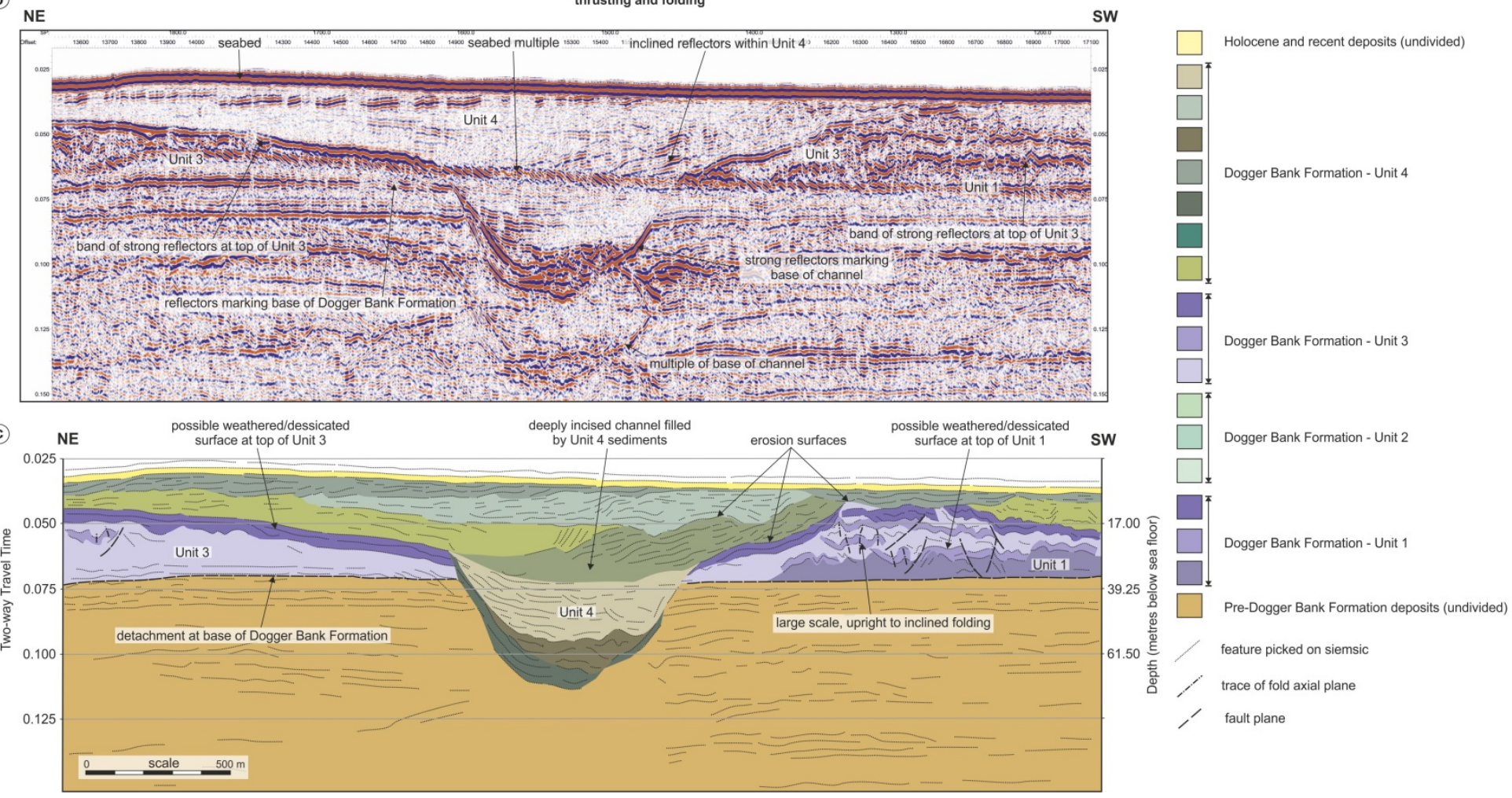

Figure 2 


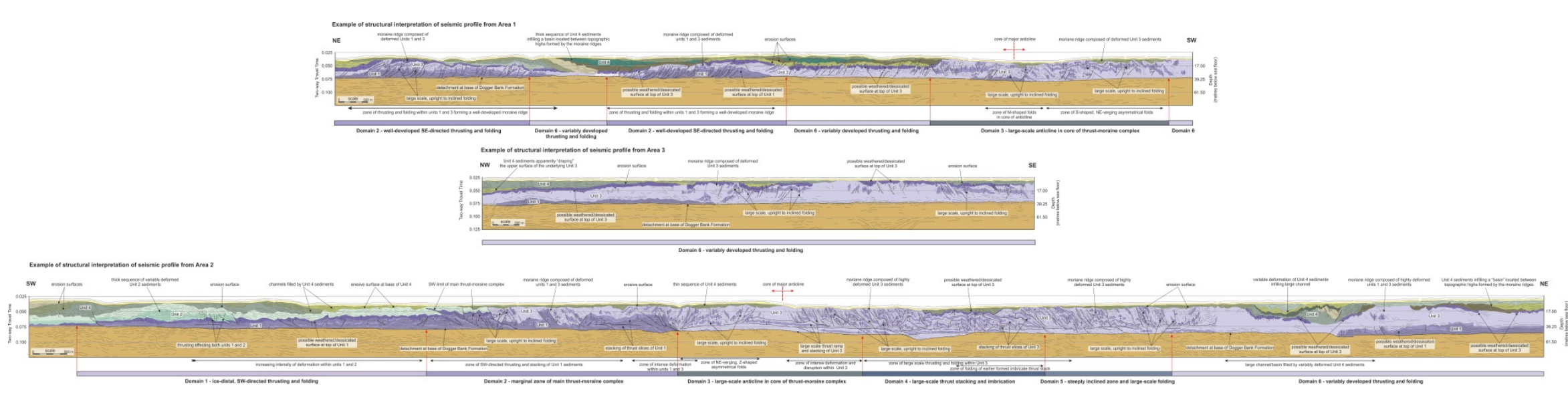

Figure 3 


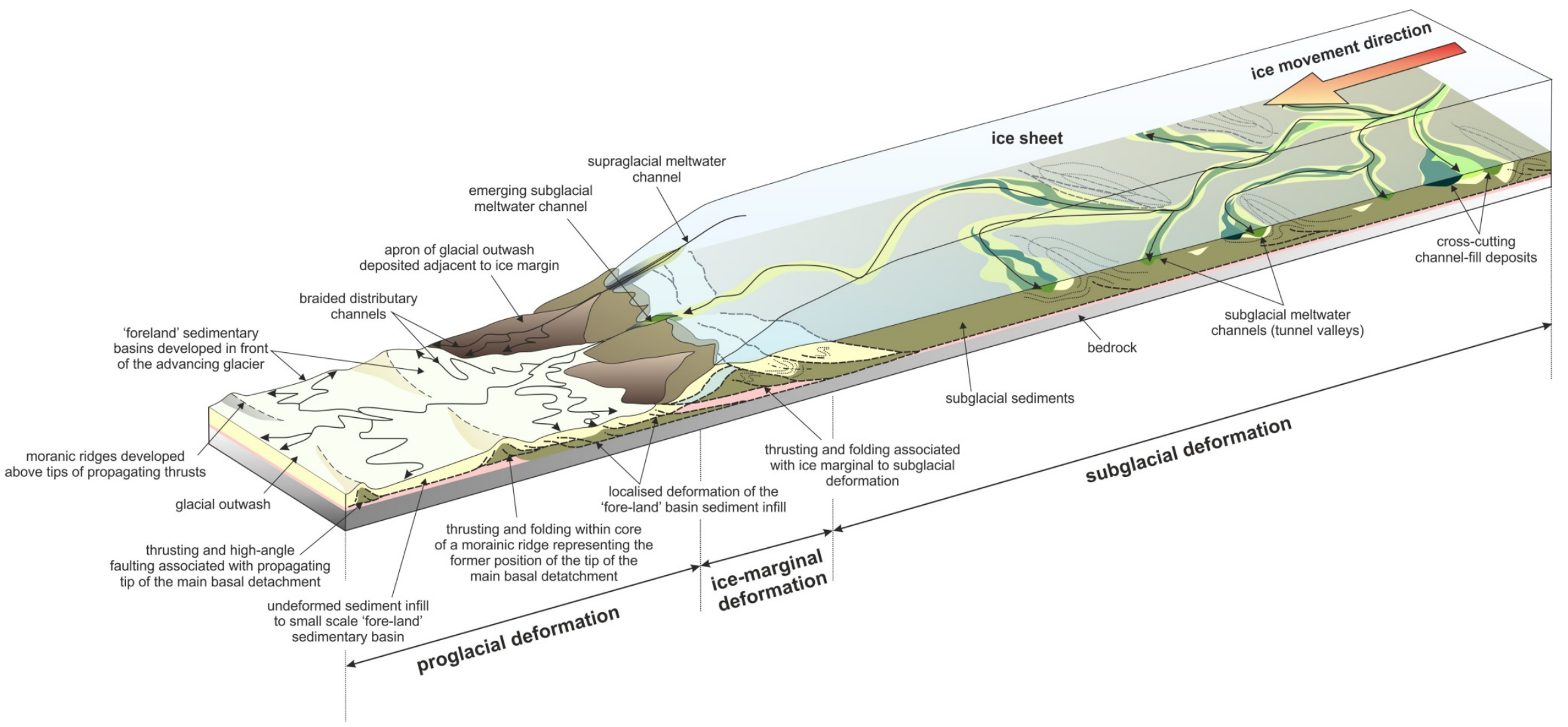

\section{Figure 4}




\section{Figure Captions}

Figure 1. (a) Map showing the location of Dogger Bank within the southern central North Sea. Also shown are the extend of the Dogger Bank Zone and study area; (b) Horizon map constructed for the top of the Basal and Older Dogger Bank Formation units. Also shown are the location of the three areas which formed the focus of the detailed analysis of the structural and sedimentary architecture of the Dogger Bank Formation; and (c) Map of the buried glacial landscape concealed within the Dogger Bank Formation comprising a suite of topographically higher arcuate moraine ridges separated by lower lying basinal areas and meltwater channels.

Figure 2. (a) Example of the structural interpretation of seismic profile from Area 1; (b) Extract of the seismic profile showing the nature of the high resolution data obtained during the site survey of the Dogger Bank Zone; and (c) Detailed interpretation of the extract of the seismic profile shown in (b) showing a deeply incised channel filled by Unit 4 sediments and cutting down into the underlying pre-Dogger Bank Formation.

Figure 3. Examples of the structural interpretations of three seismic profiles from (a) Area 1; (b) Area 3 and (c) Area 2 (see text for details).

Figure 4. Schematic 3D block diagram showing the relationships between deformation and sedimentation at the in front (proglacial), at the margin (ice-marginal) and beneath (subglacial) an ice sheet. 